\title{
Migration and Life Satisfaction: Evidence from Latin America
}

\author{
Mauricio Cárdenas \\ Brookings Institution - Washington, DC \\ Vincenzo Di Maro \\ Inter-American Development Bank • Washington, DC \\ Isaac Sorkin
}

Brookings Institution - Washington, DC

\begin{abstract}
Using data from the Gallup World Poll and Latinobarómetro, we examine the relationship between life satisfaction, vulnerabilities, and migration in Latin America. We look at three kinds of insecurities: nutritional, personal, and job insecurity. We find that controlling for income, migration experience by a household member increases life satisfaction of the respondent. We also find, however, that nutritional insecurities interact negatively with migration. In other words, hunger has a devastating effect on happiness, especially in households where a member is absent due to migration.
\end{abstract}

\section{Introduction}

Migration is an issue of major importance in Latin America. In data we discuss below, approximately a third of Latin American households report they either have a family member living abroad, or have had a family member living abroad in the last five years. The impact of migration on the individuals who remain is of obvious interest.

The bulk of the existing literature has looked at the effects of migration (and remittances) on some socioeconomic dimensions of the remaining family members. For example, Cox-Edwards and Ureta (2003) show that in El Salvador children in households receiving remittances are less likely to leave school, Hildebrandt and McKenzie (2005) find that in Mexican households with migrants, newborns are more likely to have higher birth weight and to be delivered by a professional doctor, and Lopez-Cordova (2005) concludes that in Mexican municipalities with more remittances infant and child mortality rates are lower. However, some papers show that migration has negative consequences such as less investment by parents in some health inputs or worse academic and social performance for children with one or both migrant parents (Hildebrandt \& McKenzie, 2005; World Bank, 2006; and the citations therein). There is an intense controversy over these results in part 
because the standard econometric problems of reverse causality and selection bias that plague this literature.

A comprehensive assessment of migration is even more complex because some of its effects go beyond the realm of economic choices. Even if migration brings greater material opportunities, family disintegration can have negative effects on the quality of life. For example, Gunatilleke (1990) finds that in a sample of families from Sri Lanka who had a migrant, one-fifth reported new difficulties with children, including unruly behavior, poorer health, and signs of grief or depression. Evidence of this sort underscores the importance of looking at effects of migration on subjective self-assessments of well-being.

In this vein, while not looking at migration directly, the Inter-American Development Bank's remarkable synthesis of work on the "economics of happiness" as it applies to Latin America demonstrates the insights that can be gained from considering subjective assessments (Lora, 2008). For example, the "paradox of unhappy growth" suggests an explanation for why successful growth-promoting policies are not popular, even when they are Pareto-optimal: growth induces increases in expectations for economic prosperity that outstrip the recorded growth. Understanding the impact of migration on societies requires moving beyond externally verifiable measures to examine how people perceive their experiences.

The "Economics of Happiness" has launched a broad array of definitions of well-being or happiness (or life satisfaction). The goal is to craft policies to improve a broad definition of "Quality of Life," including domains ranging from employment to health to education. There is much variation in how researchers actually implement the notion of "Quality of Life" (QoL). A typical definition, from the European Foundation for the Improvement of Living and Working Conditions (e.g. Fahey, Nolan \& Whelan, 2003), considers QoL as the ability of people to attain the goals and choose the lifestyle that they want. In this paper, we use questions from polling data that ask for an overall evaluation of the respondents lives (we report the precise wording below). We will use "happiness," "satisfaction," and "well-being" interchangeably throughout in referring to this evaluative measure.

The relationship between happiness and migration is complex. The main direct channel through which migration can positively affect well-being is remittances, which provide income.' Apart from this effect, which we control for by including household income in the regressions, the other main direct effect is likely to be the insurance of consumption. For example, Yang and Choi (2007) show that in Filipino households having a migrant family member insures consumption against income shocks. Migration might have a negative impact on happiness similar to 
"loss of friendships," due to family fragmentation. As the Inter-American Development Bank (IDB) volume documents (chapter 4), the loss of all friendships for the "average" person in Latin America has an impact on happiness equivalent to income falling to one-seventh the previous level. Therefore, migration could on net have a positive or negative impact on happiness of those left behind.

In addition to these two effects, it is possible that some vulnerabilities are exacerbated by family disintegration and the lack of immediate support. In this context, we are interested in the way in which migration indirectly affects happiness through the experience of vulnerabilities. In previous work, we looked at nutritional, job and personal (safety) insecurities and found that they negatively affected happiness, with nutritional insecurity having the strongest effect and personal safety insecurities the weakest (Cardenas, Di Maro \& Mejia, 2008). In this paper we extend that work to look at the interaction effects of migration and vulnerabilities. While it is the case that migration might affect the experience of other socioeconomic factors that contribute to happiness, like age and education, we think that the interaction with vulnerabilities is one of the most interesting. This is because the main direct channels of migration on happiness - income and insurance - are likely to have strong indirect effects on vulnerabilities. In addition, the effects of actual occurrences of hunger, fear of job loss, or victimization on happiness can vary depending on whether the individual has a fragmented family.

To provide a preliminary answer to some of these questions, this paper explores the relationship between happiness and migration by examining representative individual and country-level data from the majority of Latin American and Caribbean countries. The data allow us to examine the impact of the different channels of migration on happiness: the loss of friendship channel and the income/insurance channel. In our empirical work we look at two measures of migration: having or having had a family member abroad and whether the household expects to receive help from abroad. We look at their impacts on happiness and also whether they exacerbate or mitigate the impacts of a variety of types of insecurities - personal, job and nutritional - on happiness.

We find that the "insurance" channel appears to dominate the "loss of friendship" channel and migration has a positive impact on the happiness of those left behind. Looking more closely at vulnerabilities, we find that migration increases the negative impact of nutritional insecurity on happiness but reduces the negative impact of job insecurity on happiness. Though we do control for a "personality factor," because we are not able to control for the selection process of individuals into migration, our results should be interpreted with caution. 
The finding of a positive impact of migration on the life satisfaction of migrants households is at odds with recent findings by Borraz, Pozo and Rossi (2008) on migrants from Ecuador. They find that migration reduces the happiness of those left behind and that remittances do not compensate for the family disintegration. They use data from only two communities in Ecuador and so our results are potentially more representative of the "typical" Latin American experience. Our results are, however, consistent with the bulk of the literature that shows positive impacts of remittances and migration (difficult to separate in most cases) on an array of socioeconomic variables.

\section{Data}

We primarily use the Gallup World Poll survey. The poll includes questions on a wide range of life satisfaction dimensions (overall satisfaction with life, satisfaction with one's standard of living and satisfaction with freedom to choose what to do with one's life, among others). The poll also includes two kinds of questions related to migration and several measures of nutritional, personal and job insecurity. Though two waves of data are available for Latin American and Caribbean countries - 2006 and 2007 - unfortunately each survey covers different households so that the data does not have a panel structure. The survey covers 20 LAC countries: Argentina, Belize, Bolivia, Brazil, Chile, Colombia, Costa Rica, Dominican Republic, Ecuador, El Salvador, Guatemala, Guyana, Honduras, Mexico, Nicaragua, Panama, Paraguay, Peru, Uruguay, and Venezuela. The survey includes about 1000 observations per country. We use data from both waves. Specific questions are discussed below.

We also use data from Latinobarómetro. This is an annual survey with more specialized questions for studying perceptions in Latin America. We use the pooled cross section from 1995 to 2005 for 17 LAC countries (all of those in the Gallup survey except Belize, Dominican Republic and Guyana).

As described in the introduction, we are interested in the relationship between insecurity, migration and happiness. The Gallup World Poll and Latinobarómetro provide a number of measures of each. We report and discuss the wording of each of the measures that we use.

We use three "satisfaction" measures from the Gallup World Poll:

- Overall satisfaction with life (normally referred as the ladder question): From zero to ten, where do you personally feel at this time, assuming that the higher score the better you feel about your life, and the lower score the worse you feel about it? 
- Satisfaction with living standards: Are you satisfied or dissatisfied with your standard of living, all the things you can buy and do?

- Satisfaction with freedom: [In your country] Are you satisfied with the freedom to choose what you do with your life?

These questions each refer to a different aspect of "well-being." The first question is the most framed of the three questions and aims to capture the most comprehensive view of how an individual perceives his or her life (it has been shown by Graham et al., 2008 that this question is more correlated with income than the others). It is the only one of these three questions that allows more than a yes or no answer. The second question,tries to focus more narrowly on economic well-being, rather than general well-being, in that it frames the issue as one of standard of living, rather than satisfaction. The ladder (or life satisfaction) question is distinct from an open ended satisfaction with living standards question. However, both provide useful information and capture different features of the overall well-being of the individual. Given their complementary nature we use both in the analysis that follows.

The third question focuses on the opportunities that individual's perceive in their home country. In the context of migration, this allows us to explore whether having a family member leave the country is correlated with one's expectations of the home country.

We use one satisfaction related question from Latinobarómetro:

- Are you satisfied with life? How much? [Answers from 1, "not satisfied at all" to 4 , "very satisfied"]

This question is very similar to the Gallup "ladder" question, and aims to capture a comprehensive view of how an individual perceives his or her life.

We use three migration related questions from the Gallup World Poll:

- Have any members of your household, aged 15 to 60 , gone to live in a foreign country permanently or temporarily in the past five years?

- Two variables: family abroad 1 (yes, still there), family abroad 2 (yes, still there and yes, has returned)

- Do you have relatives or friends who are living in another country whom you can count on to help you when you need them, or not? (help from abroad)

- Is the city or area where you live a good place or not for immigrants from other countries? 
The first two questions are the core migration related questions. They allow us to know whether the household has or has had experience with migration. The difference between currently having a family member abroad and having a returned family member is crucial. It is possible that a returned family member brings not only financial capital to the household, but also human capital, though it could also be the case that migrants who return were less "successful" abroad than those who do not return. At the same time, it means that the family member has returned and so the "loss of friendship" effect is no longer there. The third question picks up on the perceived insurance benefit of having a family member abroad. The final question is of a different nature as it looks at the opportunities that an individual perceives in their locality for outsiders. This is likely to be correlated with opportunities that an individual perceives for themselves at home and thus might pick up on the relationship between migration experience and expectations.

We also use one migration related questions from Latinobarómetro:

- Have you and your family considered moving abroad?

This question is the happiness parallel to the positive and negative selection debate in terms of migrants' skill: are those who migrate more or less satisfied?

As mentioned in the introduction, we are interested in figuring out whether families with migration are affected differently by vulnerabilities or insecurities. In particular, we consider three types of insecurities: Nutritional, job-related and victimization episodes. We use two measures of nutritional insecurity from the Gallup Poll:

- Have there been times in the past twelve months when you did not have enough money to buy food that you or your family needed? (NI money, not enough money)

- Have there been times in the past 12 months when you or your family have gone hungry? (NI hungry, gone hungry)

These measures reflect different aspects of insecurity. Someone who answers yes to the first but no to the second has outside sources of help. Answering yes to both implies that not only are they economically insecure, but that there is also no safety net.

We use measures of job insecurity from two different surveys:

- Do you think you could lose your job in the next six months? (job_insec) which is available in the Gallup Poll. 
- How worried you are of losing your job or staying unemployed in the next 12 months? "Not worried," "Just a bit worried," "Worried," "Very worried" (Latinobarómetro)

- Do you think the labour regulation protects workers in this country? "Not protected at all," "just a bit protected," "Quite protected," "Very protected" (Latinobarómetro)

- From 1 to 10 where 1 is "completely secure" and 10 is "no job security at all" how much job security do you feel you have currently? . . you had 5 years ago? (Latinobarómetro)

The job insecurity question from the Gallup World Poll provides a summary measure of all sources of worries about employment, including worries due to idiosyncratic factors, business cycle worries, or firm specific worries. As a result, it provides a measure of how economically vulnerable the respondent feels. The first Latinobarómetro question refers to perceptions of the economic climate. The second picks up perceptions of the regulatory environment as it relates to labor. A higher score is likely correlated with "rigid" labor markets. The final question combines the two and is a summary measure of perceptions of both the legal and economic environment. In principle, one would expect that individuals with more unstable jobs would be more likely to migrate. In practice, however, the respondents to these questions are the family members left behind who might worry less about the local labor market conditions if they have support from abroad.

We now turn to the issue of personal insecurity where we use five different measures from the Gallup World Poll:

- Do you feel safe walking alone at night in the city or area where you live? (safe walking)

- Have you had money or property stolen from you or another household member within the past 12 months? (stolen)

- Have you been assaulted or mugged within the past 12 months? (mugged)

- Are there gangs in the area where you live? (only in the 2007 wave) (gangs)

- Are there illicit drug trafficking or drug sales in the area where you live? (only in the 2007 wave) (drug)

The measures of personal insecurity ask about perceptions and experience. The first question measures the individual's perceptions of safety, whereas the second and third gather information on actual experiences of the respondent or their 
family member with criminal activity. In principle, the answers to these questions should be highly correlated, but it may be the case that an individual's perceptions of lack of safety lead to compensating behavior that reduce their vulnerability to theft. In this case, the individual's well-being would be negatively affected though they would not actually be victims of a crime. The question on theft includes other household members because sometimes it is ambiguous to whom household property belongs. The questions on gangs and drugs - like the first question - reflect sources of personal insecurity that may affect well-being but not be measured in the other questions. Again, it is possible that migration and victimization episodes are correlated, an issue that we discuss below.

\section{Data Summary}

Simple tabulations reveal that about $15 \%$ of households have a family member still living abroad, while $18 \%$ have had a family abroad who has returned. This means that a total of $33 \%$ of households have in the last five years had a migration experience. $40 \%$ of households feel that they can count on someone living abroad for help.

Figure 1

Summary of Migration Related Questions

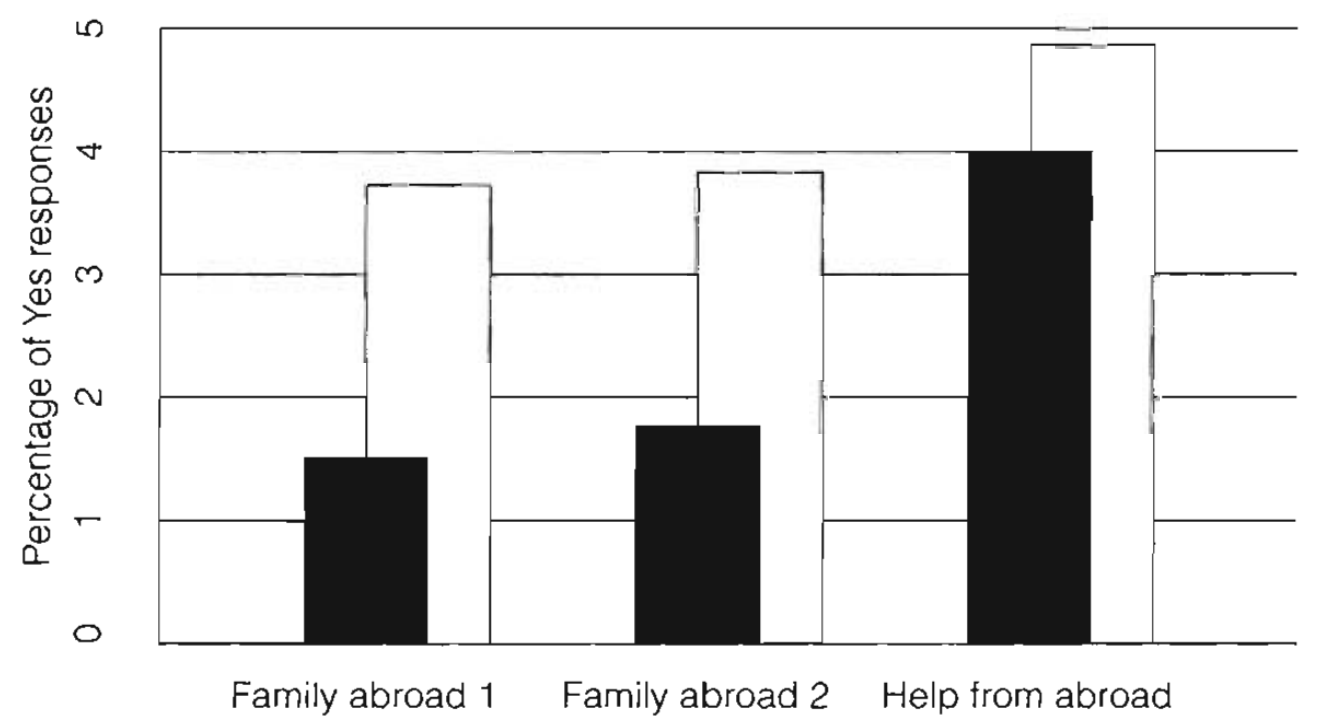

Note: Black bar is average value, white bar is standard deviation.

Source: Authors' calculations using Gallup World Poll 2007 wave.

Looking at between country variation in rate of migration experience, smaller economies have more migration. This likely has to do with the greater variety 
of economic opportunity in larger countries, it may also be related to the Alesina and Spolaore (2003) finding that smaller countries are more "open" economically. Migration experience is highest in Belize, Bolivia, Guyana and Paraguay. On both variables the yes responses are over $25 \%$, and for Guyana exceed $40 \%$. Argentina, Brazil and Chile have the lowest experiences of migration in the data. About half of migrants have returned, indicating a mix of permanent and transitory migration.

\section{Figure 2}

"Have any members of your household, aged 15 to 60 , gone to live in a foreign country permanently or temporarily in the past five years?" (proportion that answered YES, still there)

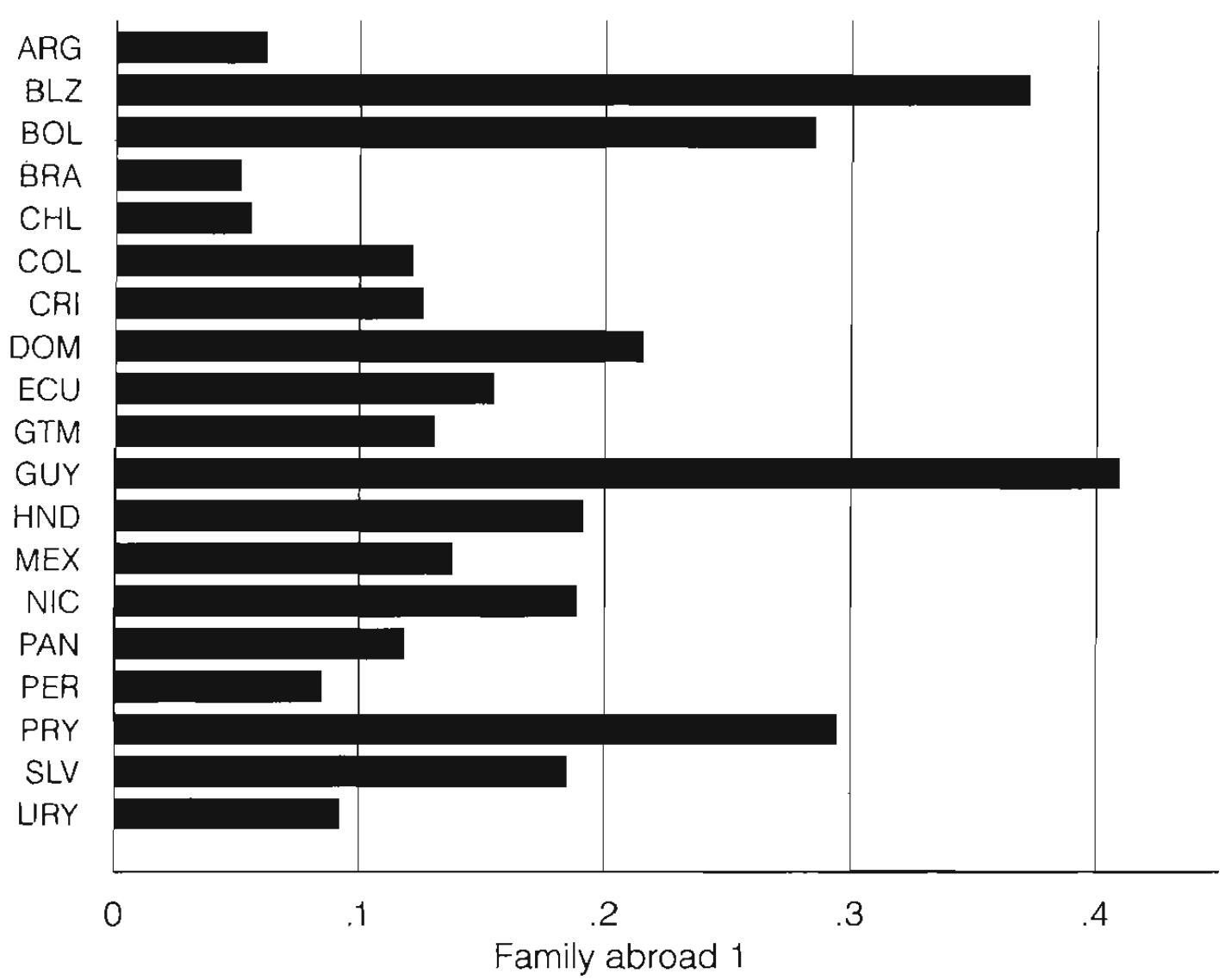

Source: Authors' calculations using Gallup World Poll 2007 wave.

Confirming that migration provides a source of financial stability to households, the "help abroad" question at the country level is quite highly correlated with the migration experience variable. In particular, Argentina, Brazil and Chile have the lowest share of households who can count on friends and relatives for help, and Belize and Guyana have the highest share. 


\section{Figure 3}

"Have any members of your household, aged 15 to 60 , gone to live in a foreign country permanently or temporarily in the past five years?" (proportion that answered YES, still there and returned)

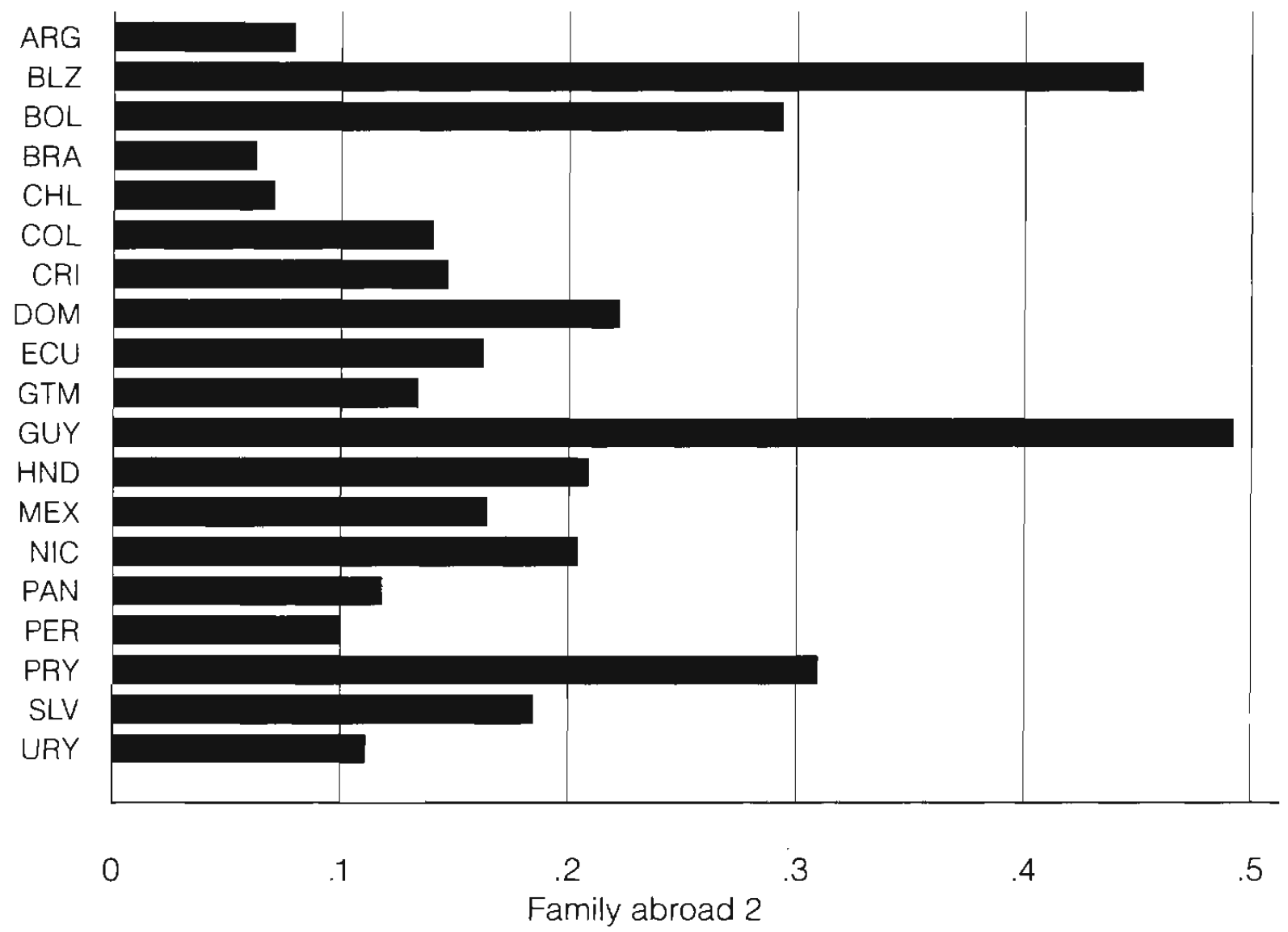

Source: Authors' calculations using Gallup World Poll 2007 wave.

The Gallup World Poll also contains data on whether the place where you live is a good place for immigrants from other countries. This picks up whether people perceive there to be opportunities for outsiders in their locale, and, as a result, whether they perceive that they have opportunities (since the information that they will use to answer this question is their own experience). The answers to this question have much lower correlation to the migrant questions than the correlation among the migrant questions. This suggests that the more salient driver of migration is perceptions of opportunity abroad, rather than at home.

There appears to be some positive selection of migrants. The level of the migration variables is increasing in the income quintile, as is help from abroad. Interestingly, so is the "good place for immigrants" variable. This implies that migrants come from more privileged locales. 


\section{Figure 4}

"Do you have relatives or friends who are living in another country whom you can count on to help you when you need them, or not?" (proportion that answered YES)

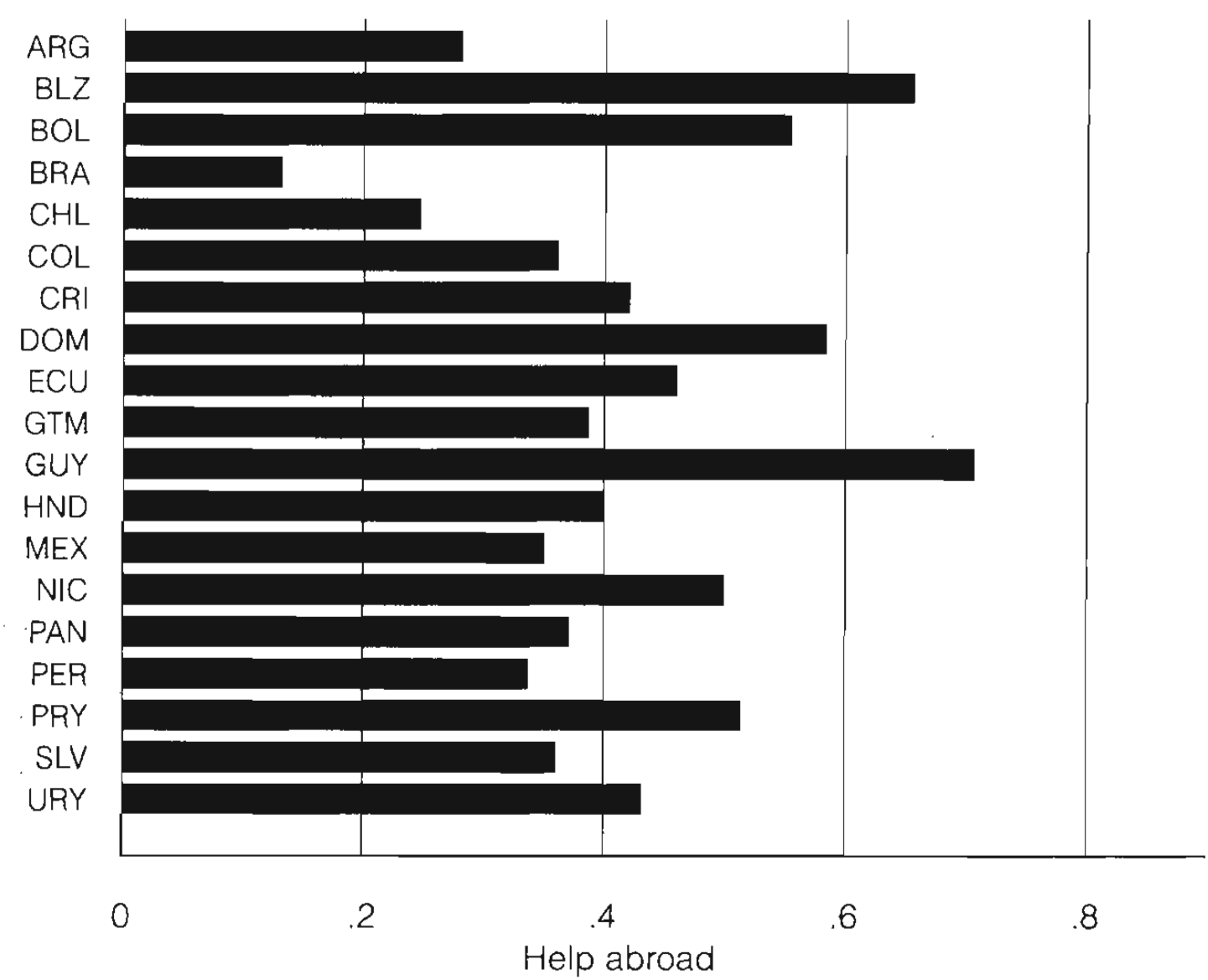

Source: Authors' calculations using Gallup World Poll 2007 wave.

Looking at the relationship between life satisfaction and "help abroad," there appears to be a u-shaped relationship. Using country-level variation in the value of the "help abroad" variable, the Lowess-smoothed curve shows that life satisfaction initially declines until the share of the population with help from abroad is about $20 \%$ and then starts increasing at 30\%. This might be because at low levels of migration, increases in the percentage of households with migration can reduce life satisfaction as they reflect worsening socioeconomic conditions in the respective country. Once migration is sufficiently high, the support from abroad effect dominates overall wellbeing perceptions. In other words, at some point, the people who benefit from migration in the form of increased security outweigh those who consider that migration reflects more limitations than opportunities. 


\section{Figure 5}

"Is the city or area where you live a good place or not a good place to live for immigrants from other countries?"

(proportion that answered good place)

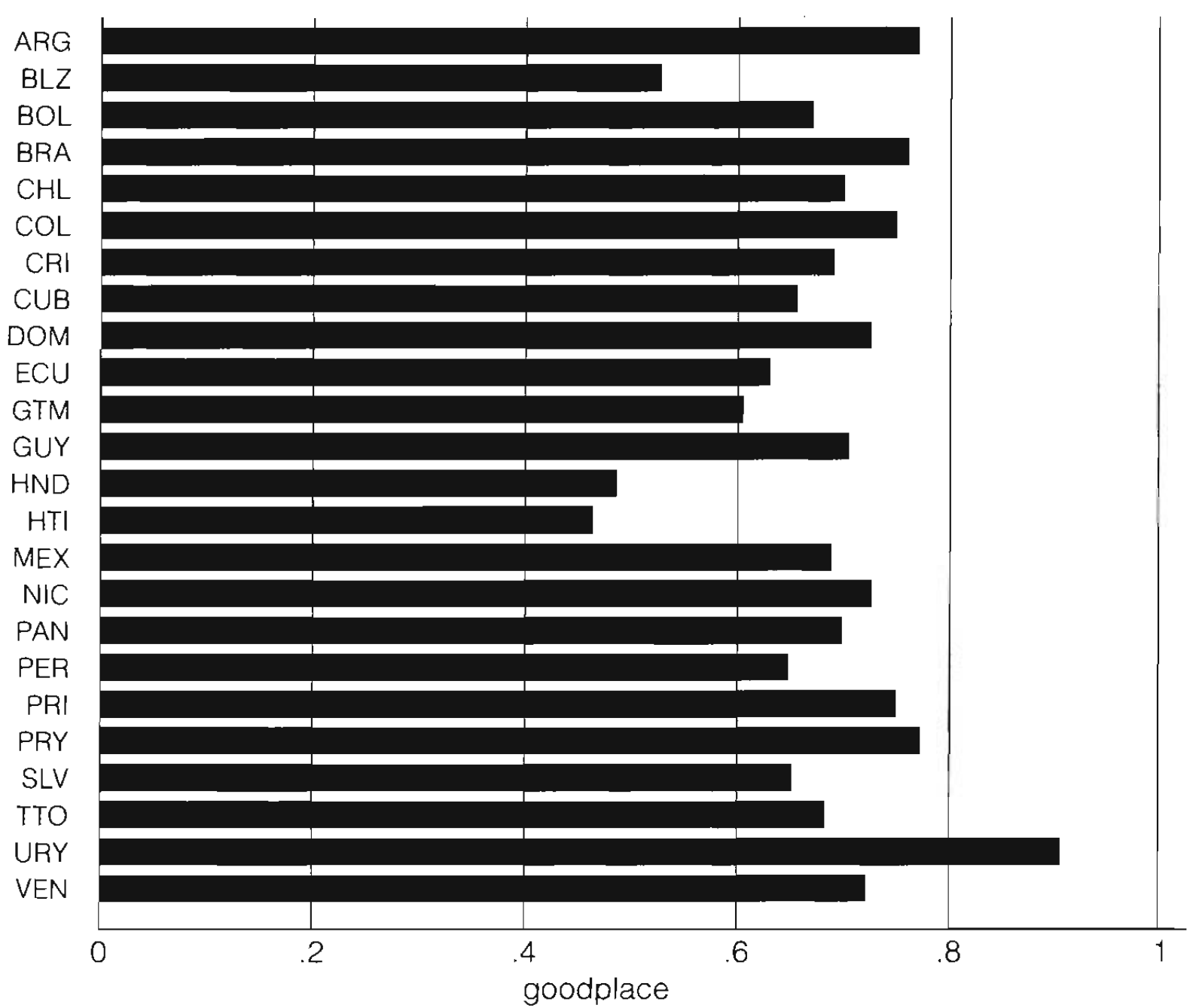

Source: Authors' calculations using Gallup World Poll 2007 wave. 


\section{Figure 6}

Migration related questions by income quintile

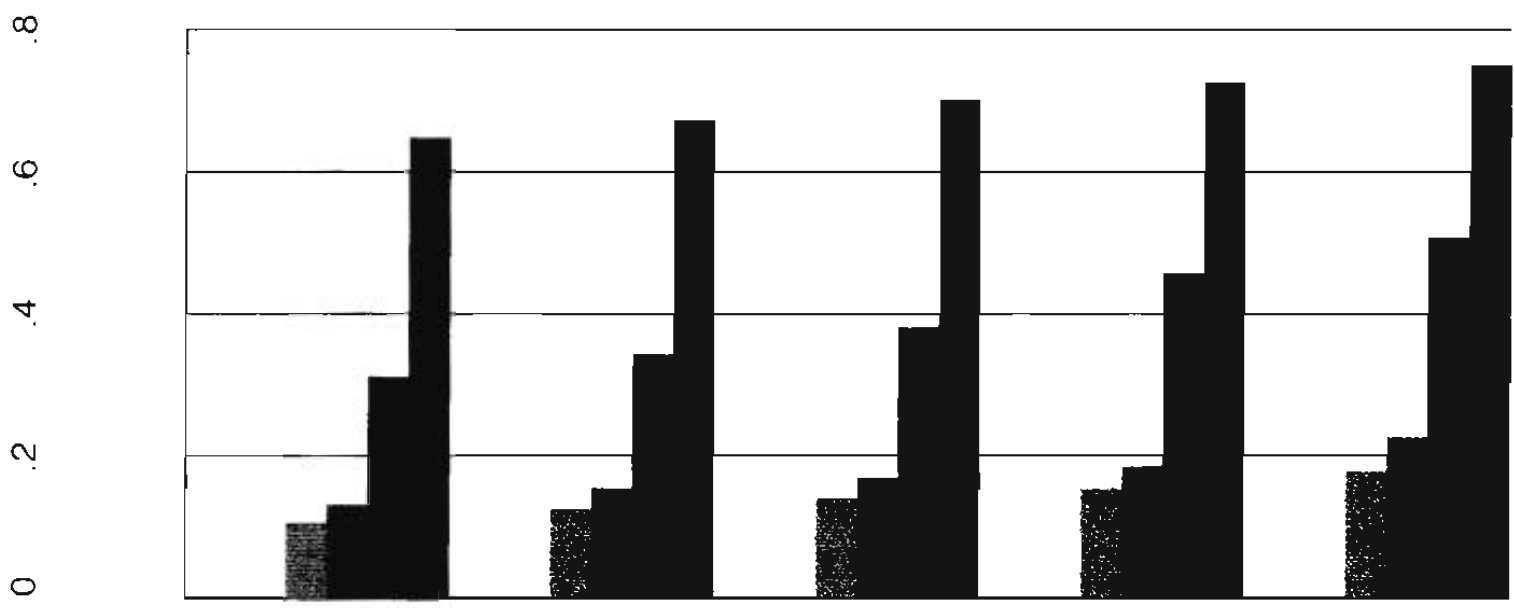

Source: Authors' calculations using Gallup World Poll wave 2007 wave.

Notes: First bar is "family abroad 1," second bar is "family abroad 2," third bar is "help from abroad," fourth bar is "good place for immigrants."

Figure 7

Life satisfaction increases if person has a relative or friend abroad he can count on

\section{Lowess smoother}

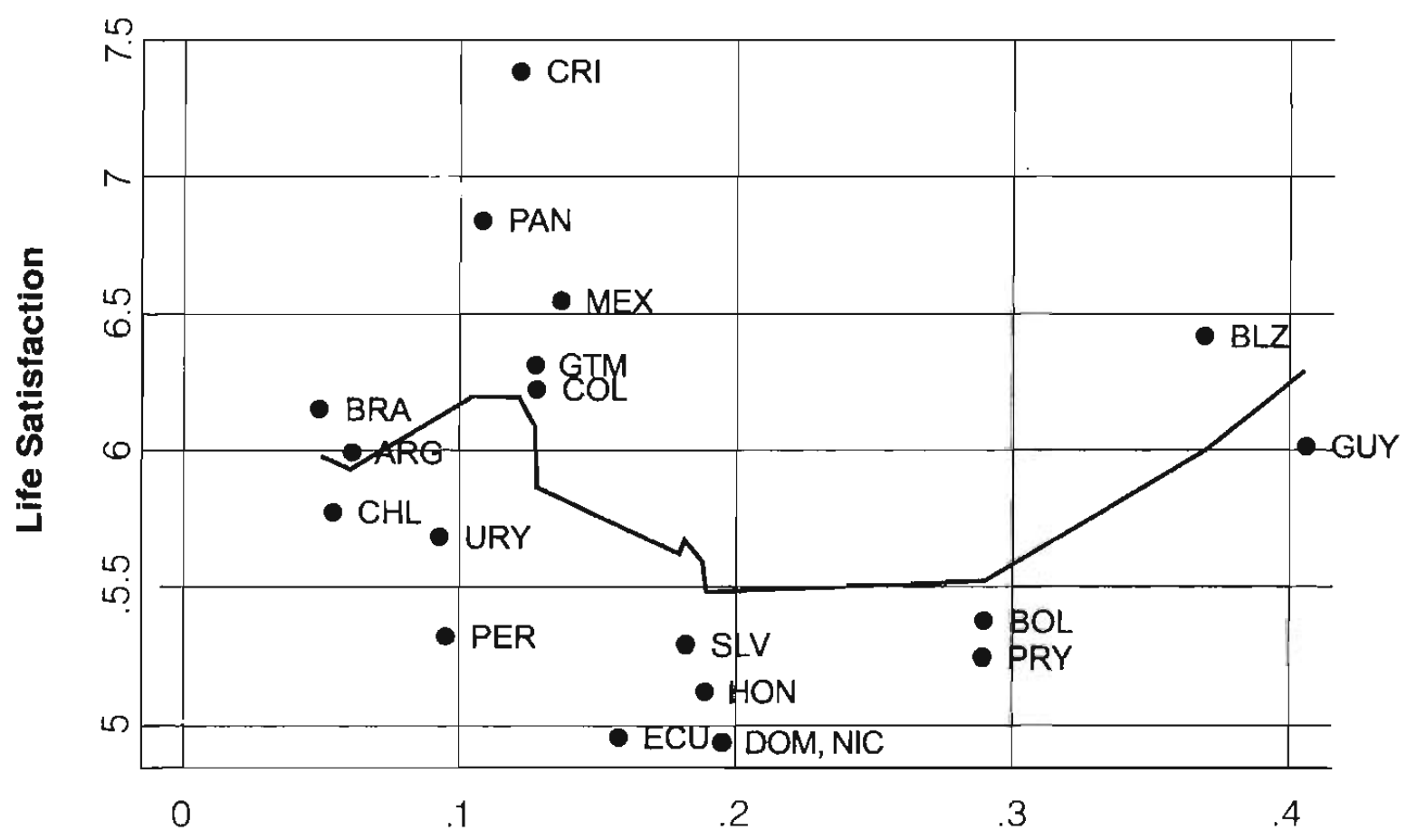

bandwidth $=.8$

Source: Authors' calculations using Gallup World Poll 2007 wave. 


\section{Econometric results}

In this section we use a regression framework to better understand the impact of migration on happiness. To do this we add migration-related variables to a standard happiness regression framework. The outcome variable of interest is perceptions of well being, and we control for measures of insecurity and other variables.

Our basic regression framework is:

$$
Y_{i, j}=\mathrm{B}_{0}+\mathrm{B}_{1} I N S_{i, j}+\mathrm{B}_{2} M_{i, j}+\mathrm{B}_{3} E X P_{i, j}+\mathrm{B}_{4} X_{i, j}+\varepsilon_{i, j}
$$

where $\mathrm{i}$ is individuals, $\mathrm{j}$ is countries, $\mathrm{Y}$ is a measure of well-being, INS is a measure of insecurity, $M$ is a measure of migration, EXP is a vector of alternative explanatory variables, and $\mathrm{X}$ is a vector of controls. We also interact the insecurity variables with the migration variables.

Our alternative explanatory variables, which we only use in some regressions, are the availability of social networks, the status of unemployment, the presence of health problems, whether the respondent thinks that religion is important, being married, being widowed, and experiencing depression.

Depending on which survey we are using we have a different set of controls. In the Gallup pool we use country and time fixed effects, the income bracket of the individual, and the age of the respondent. The income question asks for income over the previous month from all sources, including remittances (which it mentions explicitly). All our major regressions include the income control, which means that we are measuring the effect of migration on happiness above and beyond the income effects of remittances. When we use the Latinobarómetro data we include country fixed effects, socioeconomic level of the respondent, type of job the head of household, assets, and a dummy for whether the respondent is interested in politics.

There are two methodological issues in running these regressions. First, the outcome of interest is a categorical variable. Respondents report their life satisfaction on a cardinal, discrete, scale and so standard OLS is not correct. They report "7," where they could mean 6.8 or 7.2. We use procedures from Van Praag and Ferrer-i-Carbonnell (2008) to ordinalize the data. The essence of the Corrected Ordinary Least Square (COLS) method is to add an error term drawn from a normal distribution to each observation such that the respondents who report a " 7 " have, for the purposes of the regression, life satisfaction ranging from $6.5 \cdot 7.5$, with the plurality of the observations still at 7.0. We also use Pooled Ordinary Least Square (POLS), which is essentially an ordered probit. 
The second major methodological concern is that individuals have unobserved psychological traits that affect their level of happiness and might bias results. To correct for this, we use methods from Van Praag and Ferrer-i-Carbonnell (2008). They note that the psychological traits that affect answers to one question are likely to affect answers to all questions. Therefore, the ways in which an individual's responses vary from the mean response conditional on other characteristics contains information about their idiosyncratic psychological traits. In practice, we take the residuals from regressions of each life satisfaction variable on the same set of explanatory variables. We calculate the principal component of the residuals for each individual and use this as a measure of the unobservable psychological traits. While it is a little unclear what precise psychological trait this captures, it is roughly "optimism/pessimism" in outlook that affects all other responses.

Our first set of regressions reports the effects of migration on life satisfaction using the COLS method that ordinalizes the life satisfaction variable. Because of high correlation among the migration variables, we enter each into separate regressions. We also show results with and without the "personality trait factor." Our alternative explanatory variables have signs and relative magnitudes that we expect. As elsewhere in the literature, the availability of social networks has a very large and positive impact on satisfaction, indicating the importance of friendship in happiness. Experiencing depression is of opposite sign but equal magnitude. Health problems also reduce happiness, but by less than half the amount as depression. Thinking that religion is important increases happiness, by roughly the same magnitude as health problems decrease it. Being employed increases happiness by about half as much as thinking that religion is important. Interestingly, in some regressions being a widow increases happiness, and by about as much as being employed. Finally, being married exerts a negative influence on happiness, but the magnitude is quite small, and the variable is statistically insignificant in all regressions.

The family abroad variables are positive and of the same magnitude and significance as the "status of unemployment" variable. Having, or having had, a family member abroad, appears to have roughly the same impact on life satisfaction as being employed. Currently having a family member abroad has a larger impact than having had a family member abroad in the past. When we control for the personality factor the statistical significance goes away. The "help from abroad" variable shows up as significant even when we control for the personality factor. It is roughly twice the magnitude of the family abroad variable. The greater magnitude and significance of the "help from abroad" variable confirms what the remittance literature suggests: the major impact on well-being of migration is through the abil- 
ity of the migrants to provide economically for family and friends at home. In these regressions we control for income, so this reflects an effect on happiness in addition to the increase in income, likely the insurance channel.

\section{Table 1}

\section{Life satisfaction (ladder question) and migration -} Gallup, individual data

\begin{tabular}{|c|c|c|c|c|c|c|}
\hline & $\begin{array}{c}1 \\
\text { OLS }\end{array}$ & OLS & $\begin{array}{c}3 \\
\text { OLS } \\
\end{array}$ & $\begin{array}{c}4 \\
\text { OLS }\end{array}$ & $\begin{array}{c}5 \\
\text { OLS }\end{array}$ & $\begin{array}{c}6 \\
\text { OLS }\end{array}$ \\
\hline Family abroad 1 & $\begin{array}{c}0.108^{\star *} \\
(0.053)\end{array}$ & & $\begin{array}{c}0.061 \\
(0.046)\end{array}$ & & & \\
\hline Family abroad 2 & & $\begin{array}{c}0.082^{\star} \\
(0.048)\end{array}$ & & $\begin{array}{c}0.052 \\
(0.047)\end{array}$ & & \\
\hline Help from abroad & & & & & $\begin{array}{l}0.240^{\star \star \star} \\
(0.052)\end{array}$ & $\begin{array}{l}0.128^{\star \star \star} \\
(0.045)\end{array}$ \\
\hline Personality trait factor & & & $\begin{array}{l}1.007^{\star \star \star} \\
(0.013)\end{array}$ & $\begin{array}{l}1.007^{\star \star \star} \\
(0.013)\end{array}$ & & $\begin{array}{l}1.005^{\star \star \star} \\
(0.013)\end{array}$ \\
\hline Availability of social networks & $\begin{array}{l}0.630^{\star \star \star \star} \\
(0.071)\end{array}$ & $\begin{array}{l}0.631^{\star \star \star} \\
(0.071)\end{array}$ & $\begin{array}{l}0.727^{\star \star \star} \\
(0.059)\end{array}$ & $\begin{array}{l}0.727^{\star \star \star *} \\
(0.059)\end{array}$ & $\begin{array}{l}0.595^{\star \star \star \star} \\
(0.070)\end{array}$ & $\begin{array}{l}0.706^{\star \star \star} \\
(0.059)\end{array}$ \\
\hline Status of unemployment & $\begin{array}{c}0.114^{\star \star} \\
(0.049)\end{array}$ & $\begin{array}{l}0.114^{\star \star} \\
(0.049)\end{array}$ & $\begin{array}{c}0.056 \\
(0.044)\end{array}$ & $\begin{array}{c}0.056 \\
(0.044)\end{array}$ & $\begin{array}{c}0.111^{\star \star} \\
(0.049)\end{array}$ & $\begin{array}{c}0.053 \\
(0.044)\end{array}$ \\
\hline Presence of health problems & $\begin{array}{l}-0.260^{\star \star \star} \\
(0.081)\end{array}$ & 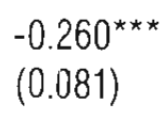 & $\begin{array}{l}* 0.211^{\star \star \star} \\
(0.048)\end{array}$ & $\begin{array}{l}-0.211^{\star \star \star} \\
(0.048)\end{array}$ & $\begin{array}{l}-0.258^{\star \star \star} \\
(0.082)\end{array}$ & $\begin{array}{l}-0.212^{\star \star \star} \\
(0.048)\end{array}$ \\
\hline Think religion is important & $\begin{array}{l}0.250^{\star \star \star \star} \\
(0.071)\end{array}$ & $\begin{array}{l}0.251^{\star \star \star} \\
(0.071)\end{array}$ & $\begin{array}{l}0.247^{\star \star \star} \\
(0.061)\end{array}$ & $\begin{array}{l}0.247^{\star \star \star \star} \\
(0.061)\end{array}$ & $\begin{array}{l}0.244^{\star \star \star \star} \\
(0.071)\end{array}$ & $\begin{array}{l}0.239^{\star \star \star} \\
(0.061)\end{array}$ \\
\hline Being married & $\begin{array}{l}-0.067 \\
(0.052)\end{array}$ & $\begin{array}{l}-0.067 \\
(0.052)\end{array}$ & $\begin{array}{l}-0.050 \\
(0.041)\end{array}$ & $\begin{array}{l}-0.051 \\
(0.041)\end{array}$ & $\begin{array}{l}-0.062 \\
(0.052)\end{array}$ & $\begin{array}{l}-0.050 \\
(0.042)\end{array}$ \\
\hline Being widow & $\begin{array}{c}0.113 \\
(0.101)\end{array}$ & $\begin{array}{c}0.114 \\
(0.101)\end{array}$ & $\begin{array}{l}0.140^{* *} \\
(0.067)\end{array}$ & $\begin{array}{l}0.140^{\star \star} \\
(0.067)\end{array}$ & $\begin{array}{c}0.118 \\
(0.103)\end{array}$ & $\begin{array}{l}0.145^{\star \star} \\
(0.068)\end{array}$ \\
\hline Experienced depression & $\begin{array}{l}-0.666^{\star \star \star} \\
(0.075)\end{array}$ & $\begin{array}{l}-0.666^{\star \star \star} \\
(0.075)\end{array}$ & $\begin{array}{l}-0.654^{\star \star \star} \\
(0.064)\end{array}$ & $\begin{array}{l}-0.655^{\star \star \star} \\
(0.064)\end{array}$ & $\begin{array}{l}-0.654^{\star \star \star} \\
(0.074)\end{array}$ & $\begin{array}{l}-0.645^{\star \star \star} \\
(0.062)\end{array}$ \\
\hline Number of observations & 11,773 & 11,773 & 9,500 & 9,500 & 11,779 & 9,508 \\
\hline R2 & 0.198 & 0.198 & 0.599 & 0.598 & 0.198 & 0.598 \\
\hline
\end{tabular}

Note: $.01-{ }^{\star \star *} ; .05-{ }^{* *} ; .1-*$

Notes: Standard errors clustered at country level; Country and time fixed effects are included; Control included: income Gallup brackets; Age categories

The second set of regressions uses the POLS method, which is essentially an ordered probit, and asks whether you are satisfied with living standards, rather 
than to what extent. The qualitative results of this regression are similar to the results from the COLS regressions. The main change is that the difference between the magnitudes of the two "family abroad" variables increases. Not surprisingly, having a family member abroad currently has more of an impact on happiness than having had one in the past. And the help from abroad variable is the largest in magnitude (fifty percent larger than the "status of unemployment" variable) and the only one that is statistically significant.

\section{Table 2}

Satisfaction with living standards (1 if satisfied) and migration Gallup, individual data

\begin{tabular}{lccc} 
& $\begin{array}{c}\mathbf{1} \\
\text { Probit }\end{array}$ & $\begin{array}{c}\mathbf{2} \\
\text { Probit }\end{array}$ & $\begin{array}{c}\mathbf{3} \\
\text { Probit }\end{array}$ \\
\hline Family abroad 1 & 0.020 & & \\
Family abroad 2 & $(0.015)$ & & \\
Help from abroad & & 0.011 & \\
& & $(0.014)$ & \\
Availability of social networks & & & $0.033^{\star \star \star}$ \\
Status of unemployment & $0.147^{\star \star \star}$ & $0.147^{\star \star \star}$ & $(0.012)$ \\
& $(0.019)$ & $(0.019)$ & $0.142^{\star \star \star}$ \\
Presence of health problems & $0.022^{\star \star}$ & $0.022^{\star \star}$ & $0.019)$ \\
& $(0.009)$ & $(0.009)$ & $(0.009)$ \\
Think religion is important & $-0.068^{\star \star \star}$ & $-0.067^{\star \star \star}$ & $-0.068^{\star \star \star}$ \\
Being married & $(0.015)$ & $(0.015)$ & $(0.015)$ \\
& $0.061^{\star \star \star}$ & $0.061^{\star \star \star}$ & $0.062^{\star \star \star}$ \\
Being widow & $(0.015)$ & $(0.015)$ & $(0.015)$ \\
& $0.027^{\star \star}$ & $0.027^{\star \star}$ & $0.027^{\star \star}$ \\
Experienced depression & $(0.012)$ & $(0.012)$ & $(0.012)$ \\
& 0.039 & 0.039 & 0.038 \\
Number of observations & $(0.026)$ & $(0.026)$ & $(0.026)$ \\
& $-0.165^{\star \star \star}$ & $-0.165^{\star \star \star}$ & $-0.164^{\star \star \star}$ \\
R2 & $(0.017)$ & $(0.017)$ & $(0.017)$ \\
\hline
\end{tabular}

Note: $.01-{ }^{* *} ; .05{ }^{* * *} ; .1-^{*}$

Notes: Standard errors clustered at country level; Country and time fixed effects are included; Controls included: income Gallup brackets; Age categories. 
The third set of regressions uses the COLS method and a different set of controls. In these regressions the question is whether migration compensates for insecurity. Having "help from abroad" increases life satisfaction by as much as being insecure in your job decreases life satisfaction. And both are statistically significant. The "family abroad" variables do not enter as significant, though they are of roughly similar magnitude as in the first set of regressions. Using this set of controls explains more of the variation in life satisfaction than the previous set of controls.

The fourth set of regressions interacts the migration variables with three insecurity variables: nutritional, job and personal. Confirming our previous work (Cardenas, Di Maro \& Mejia, 2008), nutritional insecurity has the strongest impact on life satisfaction followed by job insecurity and personal insecurity. In these regressions we are interested in the interaction effect: does having or having had a family member abroad - migration experience - or help from abroad exacerbate or mitigate the effect of negative effect of these vulnerabilities on life satisfaction?

We find that if you are nutritionally insecure, then migration experience makes the occurrence of nutritional insecurity worse by a third. This negative effect on happiness from the interaction of migration and nutritional insecurity is larger than the positive direct effect on happiness of migration. Thus, the net effect of migration on happiness is negative in the face of nutritional insecurity.

In contrast, migration experience makes the experience of job insecurity positive when we control for the personal psychological trait: the positive interaction of job insecurity and migration outweighs the negative impact of job insecurity. Combine that with the direct positive effect of migration, and the overall positive effect is quite strong.

The regressions on personal insecurity find a very small direct effect on happiness (less than one-tenth the size of nutritional insecurity), that is never statistically significant and sometimes positive, which runs counter to expectations. The interaction with family abroad is negative, but never statistically significant, and on the same order of magnitude as the direct effect of migration experience. The direction of the interaction of migration and personal insecurity is thus consistent with what we found for nutritional insecurities, where the interaction of migration and insecurities is negative.

A surprising finding is the difference on the sign of the interaction effects of migration and different vulnerabilities. Here we expect consistent -- and negative - signs across the three kinds of vulnerabilities because we pick up the same effect of family fragmentation making a given negative life experience harder to deal with. Consistent with this theory the interaction of migration and nutritional 


\section{Table 3}

Life satisfaction (ladder question), migration and types of insecurities Gallup, individual data

\begin{tabular}{|c|c|c|c|c|c|c|}
\hline & $\begin{array}{c}1 \\
\text { OLS }\end{array}$ & $\begin{array}{c}2 \\
\text { OLS }\end{array}$ & $\begin{array}{c}3 \\
\text { OLS }\end{array}$ & $\begin{array}{c}4 \\
\text { OLS }\end{array}$ & $\stackrel{5}{\text { OLS }}$ & $\begin{array}{c}6 \\
\text { OLS }\end{array}$ \\
\hline Family abroad 1 & $\begin{array}{r}0.054 \\
(0.110)\end{array}$ & & $\begin{array}{c}0.081 \\
(0.083)\end{array}$ & & & \\
\hline Family abroad 2 & & $\begin{array}{c}0.034 \\
(0.091)\end{array}$ & & $\begin{array}{c}0.086 \\
(0.074)\end{array}$ & & \\
\hline Help from abroad & & & & & $\begin{array}{l}0.212^{\star \star \star} \\
(0.073)\end{array}$ & $\begin{array}{l}0.123^{\star \star \star} \\
(0.039)\end{array}$ \\
\hline Personality trait factor & & & $\begin{array}{l}0.992^{\star \star \star} \\
(0.018)\end{array}$ & $\begin{array}{l}0.992^{\star \star \star} \\
(0.018)\end{array}$ & & $\begin{array}{l}0.988^{\star \star \star} \\
(0.018)\end{array}$ \\
\hline Nutritionai insecurity & $\begin{array}{l}-0.638^{\star \star \star} \\
(0.099)\end{array}$ & $\begin{array}{l}-0.638^{\star \star \star} \\
(0.099)\end{array}$ & $\begin{array}{l}-0.694^{\star \star \star} \\
(0.080)\end{array}$ & $\begin{array}{l}-0.694^{\star \star \star} \\
(0.080)\end{array}$ & $\begin{array}{l}-0.626^{\star \star \star} \\
(0.099)\end{array}$ & $\begin{array}{l}-0.683^{\star \star \star} \\
(0.080)\end{array}$ \\
\hline Job Insecurity & $\begin{array}{l}-0.366^{\star \star \star} \\
(0.094)\end{array}$ & $\begin{array}{l}-0.366^{\star \star \star} \\
(0.093)\end{array}$ & $\begin{array}{l}-0.157^{\star} \\
(0.084)\end{array}$ & $\begin{array}{l}-0.156^{\star} \\
(0.084)\end{array}$ & $\begin{array}{l}-0.354^{\star \star \star} \\
(0.090)\end{array}$ & $\begin{array}{c}-0.150^{\star} \\
(0.081)\end{array}$ \\
\hline 1 victimization issue & $\begin{array}{l}-0.047 \\
(0.093)\end{array}$ & $\begin{array}{l}-0.048 \\
(0.093)\end{array}$ & $\begin{array}{l}-0.140^{\star \star *} \\
(0.052)\end{array}$ & $\begin{array}{l}-0.141^{\star * *} \\
(0.053)\end{array}$ & $\begin{array}{l}-0.047 \\
(0.092)\end{array}$ & $\begin{array}{l}-0.135^{\star \star \star} \\
(0.051)\end{array}$ \\
\hline 2 victimization events & $\begin{array}{c}0.008 \\
(0.088)\end{array}$ & $\begin{array}{c}0.008 \\
(0.088)\end{array}$ & $\begin{array}{l}-0.001 \\
(0.060)\end{array}$ & $\begin{array}{l}-0.002 \\
(0.060)\end{array}$ & $\begin{array}{c}0.000 \\
(0.087)\end{array}$ & $\begin{array}{l}-0.004 \\
(0.059)\end{array}$ \\
\hline 3 victimization events & $\begin{array}{c}0.048 \\
(0.104)\end{array}$ & $\begin{array}{c}0.049 \\
(0.105)\end{array}$ & $\begin{array}{c}0.103 \\
(0.091)\end{array}$ & $\begin{array}{c}0.101 \\
(0.092)\end{array}$ & $\begin{array}{c}0.018 \\
(0.110)\end{array}$ & $\begin{array}{c}0.089 \\
(0.095)\end{array}$ \\
\hline 4 victimization events & $\begin{array}{l}-0.065 \\
(0.168)\end{array}$ & $\begin{array}{l}-0.065 \\
(0.168)\end{array}$ & $\begin{array}{c}0.164 \\
(0.115)\end{array}$ & $\begin{array}{c}0.163 \\
(0.116)\end{array}$ & $\begin{array}{l}-0.052 \\
(0.169)\end{array}$ & $\begin{array}{c}0.182 \\
(0.124)\end{array}$ \\
\hline Availability of social networks & $\begin{array}{l}0.447^{\star \star \star} \\
(0.087)\end{array}$ & $\begin{array}{l}0.447^{\star \star \star} \\
(0.086)\end{array}$ & $\begin{array}{l}0.629^{\star \star \star} \\
(0.057)\end{array}$ & $\begin{array}{l}0.628^{\star \star \star} \\
(0.057)\end{array}$ & $\begin{array}{l}0.412^{\star \star \star} \\
(0.087)\end{array}$ & $\begin{array}{l}0.611^{\star \star \star} \\
(0.057)\end{array}$ \\
\hline Presence of health problems & $\begin{array}{l}-0.220^{\star \star} \\
(0.105)\end{array}$ & $\begin{array}{l}-0.220^{\star \star} \\
(0.105)\end{array}$ & $\begin{array}{l}-0.178^{\star \star \star} \\
(0.055)\end{array}$ & $\begin{array}{l}-0.178^{\star \star \star} \\
(0.055)\end{array}$ & $\begin{array}{l}-0.235^{\star \star} \\
(0.106)\end{array}$ & $\begin{array}{l}-0.191^{\star \star *} \\
(0.054)\end{array}$ \\
\hline Think religion is important & $\begin{array}{l}0.251^{\star \star \star} \\
(0.094)\end{array}$ & $\begin{array}{l}0.251^{\star \star \star} \\
(0.093)\end{array}$ & $\begin{array}{l}0.238^{\star \star \star} \\
(0.067)\end{array}$ & $\begin{array}{l}0.238^{\star \star \star} \\
(0.067)\end{array}$ & $\begin{array}{l}0.235^{\star \star} \\
(0.096)\end{array}$ & $\begin{array}{l}0.228^{\star \star \star} \\
(0.069)\end{array}$ \\
\hline Being married & $\begin{array}{l}-0.066 \\
(0.070)\end{array}$ & $\begin{array}{l}-0.065 \\
(0.070)\end{array}$ & $\begin{array}{l}-0.023 \\
(0.053)\end{array}$ & $\begin{array}{l}-0.023 \\
(0.054)\end{array}$ & $\begin{array}{l}-0.056 \\
(0.069)\end{array}$ & $\begin{array}{l}-0.020 \\
(0.053)\end{array}$ \\
\hline Being widow & $\begin{array}{l}-0.047 \\
(0.205)\end{array}$ & $\begin{array}{l}-0.047 \\
(0.204)\end{array}$ & $\begin{array}{c}0.142 \\
(0.159)\end{array}$ & $\begin{array}{c}0.141 \\
(0.159)\end{array}$ & $\begin{array}{l}-0.036 \\
(0.201)\end{array}$ & $\begin{array}{c}0.143 \\
(0.158)\end{array}$ \\
\hline Experienced depression & $\begin{array}{l}-0.537^{\star \star \star} \\
(0.112)\end{array}$ & $\begin{array}{l}-0.537^{\star \star \star} \\
(0.112)\end{array}$ & $\begin{array}{l}-0.563^{\star \star \star} \\
(0.076)\end{array}$ & $\begin{array}{l}-0.562^{\star \star \star} \\
(0.076)\end{array}$ & $\begin{array}{l}-0.521^{\star \star \star} \\
(0.111)\end{array}$ & $\begin{array}{l}-0.549^{\star \star \star} \\
(0.074)\end{array}$ \\
\hline Number of observations & 4,560 & 4,560 & 3,843 & 3,843 & 4,559 & 3,842 \\
\hline $\mathrm{R} 2$ & 0.230 & 0.230 & 0.621 & 0.621 & 0.231 & 0.620 \\
\hline
\end{tabular}

Note: 01 - $^{\star \star *} ; .05-{ }^{* \star} ; .1$ - $^{*}$

Notes: Standard errors clustered at country level; Country and time fixed effects are included; Controls included: income Gallup brackets; Age categories. 
and personal insecurities are mostly negative, but the sign on the interaction of job insecurity and migration is positive, which is somewhat of a puzzle.

The results on "help from abroad" confirm that it is family fragmentation rather than availability of insurance that is driving our results. In our baseline regressions, help from abroad was at least half as large in magnitude as the other two migration-related variables and always statistically significant. This roughly captures a strong insurance effect. However, in the regressions in Table 4, the help from abroad variable - when interacted with vulnerabilities - is always insignificant and very small in magnitude. This suggests that it is not insurance that is important in the way migration interacts with vulnerabilities, but instead the effect of the lack of physical presence of a family member.

The fifth set of regressions reports regressions on the effects of migration on the satisfaction with freedom to choose within your own country. Having seen others migrate might reduce an individual's perceptions of freedom to choose within their own country because the observation of others' greater choices abroad might reduce perceptions of choices at home. The regression results bear this out in terms of sign, but the magnitudes are very small.

A related set of questions is addressed in the sixth set of regressions. Latinobarometro includes a question on whether you have considered moving abroad. Respondents who have considered moving abroad report life satisfaction that is lower by an amount commensurate with feeling "just a bit worried" about losing their job. One natural interpretation of this result is that people who consider migration are dis-satisfied with their current circumstances. If this result carries over to those who actually migrate, then this would suggest that migration can be understood as one adaptation strategy to dissatisfaction with life. If this is the case, then migrants might be drawn from an unhappy population with greater aspirations. 
Table 4

Life satisfaction (Ladder question), migration and types of insecurities Gallup, individual data

\begin{tabular}{|c|c|c|c|c|c|c|}
\hline & $\begin{array}{c}1 \\
\text { OLS }\end{array}$ & $\begin{array}{c}2 \\
\text { OLS }\end{array}$ & $\begin{array}{c}3 \\
\text { OLS }\end{array}$ & $\begin{array}{c}4 \\
\text { OLS }\end{array}$ & $\begin{array}{c}5 \\
\text { OLS }\end{array}$ & $\begin{array}{c}6 \\
\text { OLS }\end{array}$ \\
\hline Nutritional insecurity & $\begin{array}{l}-0.616^{* * *} \\
(0.099)\end{array}$ & $\begin{array}{l}-0.577^{\star \star \star \star} \\
(0.098)\end{array}$ & $\begin{array}{l}-0.645^{\star \star \star} \\
(0.072)\end{array}$ & $\begin{array}{l}-0.634^{\star \star \star} \\
(0.071)\end{array}$ & $\begin{array}{l}-0.606^{\star * \star} \\
(0.089)\end{array}$ & $\begin{array}{l}-0.702^{\star \star \star} \\
(0.065)\end{array}$ \\
\hline X Family abroad 1 & $\begin{array}{c}-0.093 \\
(0.180)\end{array}$ & & $\begin{array}{l}-0.250 \\
(0.160)\end{array}$ & & & \\
\hline$X$ Family abroad 2 & & $\begin{array}{l}-0.294 \\
(0.194)\end{array}$ & & $\begin{array}{l}-0.282^{*} \\
(0.154)\end{array}$ & & \\
\hline$X$ Help from abroad & & & & & $\begin{array}{c}-0.034 \\
(0.151)\end{array}$ & $\begin{array}{c}0.070 \\
(0.131)\end{array}$ \\
\hline Job insecurity & $\begin{array}{l}-0.411^{\star * *} \\
(0.084)\end{array}$ & $\begin{array}{l}-0.420^{\star \star *} \\
(0.086)\end{array}$ & $\begin{array}{l}-0.207^{\star *} \\
(0.088)\end{array}$ & $\begin{array}{l}-0.217^{* *} \\
(0.088)\end{array}$ & $\begin{array}{l}-0.327^{\star * * *} \\
(0.090)\end{array}$ & $\begin{array}{l}-0.166^{\star \star} \\
(0.081)\end{array}$ \\
\hline$X$ Family abroad 1 & $\begin{array}{c}0.294 \\
(0.308)\end{array}$ & & $\begin{array}{c}0.332^{*} \\
(0.176)\end{array}$ & & $\begin{array}{l}-0.218^{\star *} \\
(0.105)\end{array}$ & $\begin{array}{l}-0.218^{\star \star} \\
(0.105)\end{array}$ \\
\hline X Family abroad 2 & & $\begin{array}{c}0.319 \\
(0.294)\end{array}$ & & $\begin{array}{c}0.357^{\star \star} \\
(0.166)\end{array}$ & & \\
\hline$X$ Help from abroad & & & & & $\begin{array}{c}-0.070 \\
(0.173)\end{array}$ & $\begin{array}{c}0.047 \\
(0.094)\end{array}$ \\
\hline Personal insecurity & $\begin{array}{l}-0.040 \\
(0.077)\end{array}$ & $\begin{array}{l}-0.050 \\
(0.070)\end{array}$ & $\begin{array}{c}0.061 \\
(0.070)\end{array}$ & $\begin{array}{c}0.063 \\
(0.067)\end{array}$ & $\begin{array}{c}0.028 \\
(0.085)\end{array}$ & $\begin{array}{c}0.060 \\
(0.081)\end{array}$ \\
\hline XFamily abroad 1 & $\begin{array}{c}0.031 \\
(0.144)\end{array}$ & & $\begin{array}{c}-0.155 \\
(0.145)\end{array}$ & & & \\
\hline$X$ Family abroad 2 & & $\begin{array}{r}0.083 \\
(0.131)\end{array}$ & & $\begin{array}{l}-0.149 \\
(0.126)\end{array}$ & & \\
\hline X Help from abroad & & & & & $\begin{array}{l}-0.167 \\
(0.116)\end{array}$ & $\begin{array}{c}-0.069 \\
(0.106)\end{array}$ \\
\hline Family abroad 1 & $\begin{array}{c}0.020 \\
(0.158)\end{array}$ & & $\begin{array}{c}0.144 \\
(0.104)\end{array}$ & & & \\
\hline Family abroad 2 & & $\begin{array}{c}0.048 \\
(0.146)\end{array}$ & & $\begin{array}{c}0.155^{*} \\
(0.093)\end{array}$ & & \\
\hline Help from abroad & & & & & $\begin{array}{l}0.281^{\star \star} \\
(0.116)\end{array}$ & $\begin{array}{c}0.114 \\
(0.076)\end{array}$ \\
\hline Personality trait factor & & & $\begin{array}{l}0.991^{\star \star \star \star} \\
(0.019)\end{array}$ & $\begin{array}{l}0.991^{\star \star \star} \\
(0.019)\end{array}$ & & $\begin{array}{l}0.986^{\star \star \star \star} \\
(0.018)\end{array}$ \\
\hline Number of observations & 4,551 & 4,551 & 3,834 & 3,834 & 4,550 & 3,833 \\
\hline R2 & 0.230 & 0.231 & 0.620 & 0.621 & 0.231 & 0.619 \\
\hline
\end{tabular}

Note: $.01-^{* \star *} ; .05{ }^{* *} ; .1-^{*}$

Notes: Standard errors clustered at country level; Country and time fixed effects are included; † Controis included: income Gallup brackets; $\uparrow$ Age categories. 


\section{Table 5}

Satisfaction with freedom to choose ( 1 if satisfied) and migration Gallup, individual data

\begin{tabular}{lccc} 
& $\begin{array}{c}\mathbf{1} \\
\text { Probit }\end{array}$ & $\begin{array}{c}\mathbf{2} \\
\text { Probit }\end{array}$ & $\begin{array}{c}\mathbf{5} \\
\text { Probit }\end{array}$ \\
\hline Family abroad 1 & -0.003 & & \\
Family abroad 2 & $(0.010)$ & & \\
& & -0.003 & \\
Help from abroad & & $(0.008)$ & \\
& & & 0.016 \\
Availability of social networks & $0.075^{\star \star \star}$ & $0.075^{\star \star \star}$ & $(0.010)$ \\
& $(0.015)$ & $(0.015)$ & $0.071^{\star \star \star}$ \\
Status of unemployment & 0.006 & 0.006 & $0.014)$ \\
& $(0.008)$ & $(0.008)$ & $(0.007$ \\
Presence of health problems & $-0.024^{\star \star \star}$ & $-0.024^{\star \star \star}$ & $-0.024^{\star \star \star}$ \\
& $(0.007)$ & $(0.007)$ & $(0.007)$ \\
Think religion is important & $0.057^{\star \star \star}$ & $0.057^{\star \star \star}$ & $0.058^{\star \star \star}$ \\
Being married & $(0.016)$ & $(0.016)$ & $(0.016)$ \\
& $0.020^{\star}$ & $0.020^{\star}$ & $0.021^{\star}$ \\
Being widow & $(0.011)$ & $(0.011)$ & $(0.011)$ \\
& 0.024 & 0.024 & 0.021 \\
Experienced depression & $(0.016)$ & $(0.016)$ & $(0.015)$ \\
& $-0.055^{\star \star *}$ & $-0.055^{\star \star \star}$ & $-0.054^{\star \star \star}$ \\
Number of observations & $(0.016)$ & $(0.016)$ & $(0.015)$ \\
R2 & 11,569 & 11,569 & 11,573 \\
\hline
\end{tabular}

Note: $.01{ }^{* \star \star} ; .05-{ }^{\star *} ; .1$ - $^{*}$

Notes: Standard errors clustered at country level; Country and time fixed effects are included; Controls included: income Gallup brackets; income country: countries grouped in 6 categories (high_income_OECD; high_income_non_OECD; low income; lower_ middle_income; upper middle income); Age categories. 


\section{Table 6}

\section{Life satisfaction and migration proxy}

"Have you and your family considered moving abroad?"

Latinobarómetro, waves 2002, 2003 and 2004

\begin{tabular}{|c|c|c|c|c|}
\hline & $\begin{array}{c}1 \\
\text { OLS }\end{array}$ & ${ }^{2}$ OLS & $\stackrel{3}{\text { OLS }}$ & $\begin{array}{c}4 \\
\text { OLS }\end{array}$ \\
\hline considered moving abroad & $\begin{array}{l}-0.094^{\star \star \star} \\
(0.012)\end{array}$ & $\begin{array}{l}-0.078^{\star \star \star} \\
(0.011)\end{array}$ & $\begin{array}{l}-0.079^{\star \star \star} \\
(0.018)\end{array}$ & $\begin{array}{l}-0.067^{\star \star \star} \\
(0.017)\end{array}$ \\
\hline \multicolumn{5}{|l|}{$\begin{array}{l}\text { "Worried of losing job?" } \\
\text { step. } 1 \text { "not worried" (omitted) }\end{array}$} \\
\hline step 2 "just a bit worried" & & & $\begin{array}{l}-0.067^{\star \star \star} \\
(0.026)\end{array}$ & $\begin{array}{l}-0.064^{\star \star \star} \\
(0.020)\end{array}$ \\
\hline step 3 "worried" & & & $\begin{array}{l}-0.154^{\star \star \star} \\
(0.024)\end{array}$ & $\begin{array}{l}-0.147^{\star \star \star} \\
(0.020)\end{array}$ \\
\hline step 4 "very worried" & & & $\begin{array}{l}-0.116^{\star \star \star} \\
(0.027)\end{array}$ & $\begin{array}{l}-0.107^{\star \star *} \\
(0.022)\end{array}$ \\
\hline married & $\begin{array}{l}-0.005 \\
(0.009)\end{array}$ & $\begin{array}{l}-0.002 \\
(0.009)\end{array}$ & $\begin{array}{l}-0.014 \\
(0.013)\end{array}$ & $\begin{array}{l}-0.006 \\
(0.014)\end{array}$ \\
\hline divorced & $\begin{array}{l}-0.061^{\star \star \star} \\
(0.016)\end{array}$ & $\begin{array}{l}-0.058^{\star \star \star} \\
(0.013)\end{array}$ & $\begin{array}{l}-0.095^{\star \star \star} \\
(0.025)\end{array}$ & $\begin{array}{l}-0.087^{\star \star \star} \\
(0.025)\end{array}$ \\
\hline trust & $\begin{array}{l}0.098^{\star \star \star} \\
(0.016)\end{array}$ & $\begin{array}{l}0.085^{\star \star \star} \\
(0.016)\end{array}$ & $\begin{array}{l}0.080^{\star \star \star} \\
(0.015)\end{array}$ & $\begin{array}{l}0.068^{\star \star \star} \\
(0.015)\end{array}$ \\
\hline democracy & $\begin{array}{l}-0.041^{\star \star *} \\
(0.008)\end{array}$ & $\begin{array}{l}-0.035^{\star \star \star} \\
(0.006)\end{array}$ & $\begin{array}{l}-0.041^{* * \star} \\
(0.010)\end{array}$ & $\begin{array}{l}-0.035^{\star \star \star} \\
(0.009)\end{array}$ \\
\hline control for health satisfaction & no & yes & no & yes \\
\hline Number of observations & 35,211 & 34,729 & 19,084 & 18,845 \\
\hline $\mathrm{R} 2$ & 0.105 & 0.129 & 0.114 & 0.137 \\
\hline
\end{tabular}

Note: $.01-^{\star \star \star} ; .05-\star \star ; .1-^{\star}$

Notes: Standard errors clustered at country and year level; Sample: waves 2002, 2003 and 2004 for column 1 and 2, only 2003 and 2004 for column 3 and 4; "Worried to lose your job" measure goes from 1 (least worried) to 4 (most worried); Control variable for health satisfaction is a scale of satisfaction with health status (from 0 to 4); "social networks" refer to a question asking whether the respondent trusts other people; Controls included: country fixed effects, socio-economic level of respondent (as reported by the interviewer), type of job of head, number of assets, dummy for whether respondent is interested in politics. 


\section{Conclusion}

The "Economics of Happiness" suggests the importance of analyzing both externally verifiable and subjective measures of well-being. This paper seeks to address the question of whether migration is Pareto-improving: assuming that the migrants themselves are better off, what happens to the remaining household members? Our primary finding is that in most cases migration is such an improvement. Even controlling for income, which is likely the strongest positive channel of migration on well-being through remittances, households reporting migration experience are more satisfied than other households. This suggests that migration has positive impacts through other channels. One possibility, noted most strongly in the literature, is the insurance role of remittances. Second, it might be that income received from remittances are spent on goods that make a greater direct contribution to satisfaction - like investments in education or health - than income earned from other sources. Third, and much more speculatively, migration might affect satisfaction through changes in expectations. In particular, the observation of a better life for a family member might increase hopes for their own future.

However, we also find that those households that are nutritionally insecure, and hence the most vulnerable, are made worse off by migration. Because these regressions control for income, this is an upper bound on the negative effects of migration on well-being. This suggests that income-based measures of the pro-poor effects of migration found in Adams and Page (2005), among others, might overstate the pro-poor impacts of migration on well-being, particularly among the most vulnerable. This provides yet one more reason for strengthening the social safety net in poor areas, particularly those with heavy outflows of migrants.

\section{Note}

1. The relationship between income and happiness being itself a subject of much controversy. See, for example, Graham, Chattopadhyay, and Picon, 2008.

\section{References}

Adams, R., \& Page, J. (2005). Do international migration and remittances reduce poverty in developing countries? World Development, 33(10), 1645-1669.

Alesina, A., \& Spolaore, E. (2003). The size of nations. Cambridge, MA: MIT Press. 
Borraz, F., Pozo, S., \& Rossi, M. (2008). And what about the family back home? International migration and happiness. Universidad de la Republica. Department of Economics Working Paper No. 03/08.

Cardenas, M., Di Maro, V., \& Mejia, C. (2008). Vulnerabilities and the quality of life: An analysis based on different types of insecurities. In C. Graham \& E. Lora (Eds.), Paradox and perception: Measuring quality of life in Latin Ameri$c a$. Washington, DC: The Brookings Institution, forthcoming

Cox-Edwards, A. C., \& Ureta, M. (2003). International migration, remittances, and schooling: Evidence from El Salvador. Journal of Development Economics, 72, 429-61.

Fahey, T., Nolan, B., \& Whelan, C. T. (2003). Monitoring quality of life in Europe. Luxembourg: Office for Official Publications of the European Communities.

Graham, C., Chattopadhyay, S., \& Picon, M. (2008). The Easterlin and other paradoxes: Why both sides of the debate may be correct. In E. Diener, J. Helliwell, \& D. Kahneman (Eds.), International differences in well being. Oxford: Oxford University Press, forthcoming.

Gunatilleke, G. (1990). Sri Lanka. In G. Gunatilleke (Ed.), Migration to the Arab World: Experience of Returning Migrants. United Nations University Press.

Hildebrandt, N., \& McKenzie, D. (2005). The effects of migration on child health in México. Economia (Journal of the Latin American and the Caribbean Economic Association), 6(1), 257-289.

Lopez-Cordova, E. (2005). Globalization, migration and development: The role of migrant remittances. Economia (Journal of the Latin American and the Caribbean Economic Association), 6(1), 217-256.

Lora, Eduardo (2008). Beyond the facts: Understanding the quality of life. InterAmerican Development Bank and Harvard University Press.

Van Praag, B., \& Ferrer-i-Carbonel1, A. (2008). Happiness quantified: A satisfaction calculus approach. Oxford University Press. Revised Edition.

World Bank (2006). Economic implications of remittances and migration. Global economic prospects.

Yang, D., \& Choi, H. (2007). Are remittances insurance? Evidence from rainfall shocks in the Philippines. World Bank Economic Review, 21(2), 219-248.

\section{Biographical Sketches of Authors}

Mauricio Cardenas is Director of the Latin America Initiative and a Senior Fellow at the Brookings Institution. Formerly minister of Economic Development 
and Transportation, and director of National Planning of Colombia, his research focuses on international and development economics.

Vincenzo Di Maro is a Research Fellow at the Inter-American Development Bank. He is completing a PhD from University College London with a thesis on the evaluation of development interventions.

Isaac Sorkin is a Research Assistant in the Global Economy and Development program at the Brookings Institution. 